\title{
INFLUENCES ON AND ORIGINS OF TERRESTRIAL BIODIVERSITY OF THE SUB-ANTARCTIC ISLANDS
}

\author{
by Peter Convey
}

\author{
(with one text-figure and five tables)
}

\begin{abstract}
Convey, P. 2007 (23:xi): Influences on and origins of terrestrial biodiversity of the sub-Antarctic islands. Papers and Proceedings of the Royal Society of Tasmania 141(1): 83-94. https://doi.org/10.26749/rstpp.141.1.83 ISSN 0080-4703. British Antarctic Survey,

Natural Environment Research Council, High Cross, Madingley Road, Cambridge CB3 0ET, United Kingdom.

Email: p.convcy@bas.ac.uk

The "sub-Antarctic" is a region of the planet characterised by small and extremely isolated island landmasses set in the vastness and harsh condirions of the Southern Ocean. Although there is no universally applicable definition of the sub-Antarctic, based on eco-climatic criteria (temperature and the presence/absence of trees or woody shrubs) a useful terrestrial biogeographic region can be defined that includes only those islands which lie close to the oceanic Antarctic Polar Frontal Zone (PFZ). These range between roughly $47^{\circ} \mathrm{S}$ and $54^{\circ} \mathrm{S}$ and include South Georgia in the South Atlantic sector of the Southern Ocean, Marion and Prince Edward islands, Îles Kerguelen and Crozet, and Heard and McDonald islands in the Indian Ocean sector, and Macquarie Island in the Pacific Ocean sector. These islands have widely differing origins and geological histories. This paper provides an overview of their biodiversity and of the major patterns in biogeography. The majority of islands are of relatively recent origin, and there are only very limited indications of a more ancient biogeographical history (Gondwana-breakup timescale) to be found in the contemporary biota. Amongst the sub-Antarctic biota, there are examples supporting two general hypotheses relating to their origin: the Insulantarctic and the multiregional scenarios. Sub-Antarctic terrestrial ecosystems, which are of biodiversity and conservation significance globally, are under considerable contemporary pressure through the twin influences of possible anthropogenic climate change, and the introduction and establishment of invasive non-indigenous species.
\end{abstract}

Key Words: biogeography, colonisation, dispersal, human impacts, climate change, South Georgia, Prince Edward Islands, îles Kerguelen and Crozet, Heard Island, Macquarie Island.

\section{INTRODUCTION}

The "sub-Antarctic" is a region of the planet characterised by small and extremely isolated island landmasses set in the vastness and harsh conditions of the Southern Ocean. There is no universally accepted single geographic definition of the sub-Antarctic, although it is generally accepted as a meaningful term for a terrestrial biological region. For the purposes of this paper, the formulation of Smith (1984) will be used, which is based on eco-climatic criteria (temperature and the presencel absence of trees or woody shrubs), and includes only those islands which lie close to the oceanic Antarctic Polar Frontal Zone (PFZ). These range between roughly $47^{\circ} \mathrm{S}$ and $54^{\circ} \mathrm{S}$ and include South Georgia in the South Atlantic sector of the Southern Ocean, Marion and Prince Edward islands, Îles Kerguelen and Crozet, and Heard and McDonald islands in the Indian Ocean sector, and Macquarie Island in the Pacific Ocean sector. While limiting discussion here to these islands, it is only reasonable to recognise that they represent one stage of a continuum in environmental conditions between the more extreme environments of the islands and archipelagoes of the Continental and Maritime Antarctic (Balleny, Peter I Øya, South Shetland, South Orkney, South Sandwich Islands, Bouvetøya), and those of cold temperate oceanic islands and archipelagoes such as Diego Ramirez, the Falkland Islands, Tristan da Cunha, Gough Island, Amsterdam Island and New Zealand's shelf islands. Both the colder and warmer islands in these groups sometimes show considerable overlap in terms of common species or genera with those of the more tightly defined sub-Antarctic. This is demonstrated by bryophytes and lichens in relation with the maritime and continental Antarctic (Øvstedal \& Smith 2001, Ochyra et al. in press), and by vascular plants, particularly "megaherbs", in relation with the New Zealand shelf islands (e.g., Fell 2002). In the literature, reference has been made at different times to some or all of these as "sub-Antarctic" (e.g., Dingwall 1995, Shirihai 2002).

The different sub-Antarctic islands have little in common in terms of their age and geological origin (table 1). The geological history of some areas has been contentious until recently (e.g., the Kerguelen Plateau, Wallace et al. 2002), and this remains the case for Îles Crozet (Craig 2003). Volcanism has been involved in the formation of many. Îles Kerguelen and Heard and McDonald islands are part of the Kerguelen Plateau, itself of Gondwanan age (although the islands are much younger) (Gladczenko \& Coffin 2001). Marion and Prince Edward islands, and Îles Crozet, are shield volcanoes, which erupted $0.11-0.21 \mathrm{Ma}$ and $0.2-9 \mathrm{Ma}$ respectively (LeMasurier \& Thomson 1990). South Georgia contains continental elements that are continuous with the Andes mountain chain of South America and the Antarctic Peninsula and Scotia Arc. Macquarie Island is an uplifted piece of largely intact seafloor ophiolite complex at the junction of the Indian-Australian and Pacific tectonic plates, and is currently thought to have emerged from the sea around $0.6 \mathrm{Ma}$ (Adamson et al. 1995). Thus, with the exception of South Georgia, the majority of sub-Antarctic islands are substantially younger than the Southern Hemisphere continents, with the oldest being Îles Kerguelen at c. 39 Ma. Only two of the islands remain extensively glaciated today - Heard Island and South Georgia - although Pleistocene glaciation was also significant on Marion Island and Îles Kerguelen and Crozet.

The sub-Antarctic islands are often described as having "tundra" ecosystems. However, there are fundamental differences between these and the true tundra of the Arctic. These sub-Antarctic ecosystems experience a very strong oceanic influence and much reduced levels of seasonal 
TABLE 1

General summary of the physical characteristics of the major groups of sub-Antarctic islands ${ }^{1}$

\begin{tabular}{lccccc}
\hline & $\begin{array}{c}\text { Area } \\
\left(\mathrm{km}^{2}\right)\end{array}$ & $\begin{array}{c}\text { Altitude } \\
(\mathrm{m})\end{array}$ & $\begin{array}{c}\text { Minimum age } \\
(\mathrm{myr})\end{array}$ & $\begin{array}{c}\text { Nearest continent } \\
(\mathrm{km})\end{array}$ & $\begin{array}{c}\text { Maxinum } \\
\text { glaciation }\end{array}$ \\
\hline South Georgia & 3755 & 2950 & 120 & 2210 & complete \\
Marion & 290 & 1230 & 0.45 & 1900 & partial \\
Prince Edward & 44 & 672 & 0.21 & 1900 & no \\
Crozet & 356 & 1090 & $0.4-8.75$ & 2740 & minor \\
Kerguelen & 7200 & 1840 & 30 & 4110 & almost total \\
Heard & 368 & 2745 & 20 & 4570 & complete \\
McDonald & 2.6 & 230 & 0.079 & 5000 & minor \\
Macquarie & 128 & 433 & 0.6 & 990 & none \\
\hline
\end{tabular}

1 Data from Chown et al. (1998).

TABLE 2

Typical air temperature ranges experienced in summer and winter in the three commonly-recognised Antarctic and two Arctic biogeographical zones

\begin{tabular}{lcccc}
\hline Zone & $\begin{array}{c}\text { Months with } \\
\text { positive mean air } \\
\text { temperatures }\end{array}$ & $\begin{array}{c}\text { Mean monthly air } \\
\text { temperature range } \\
\left({ }^{\circ} \mathrm{C}\right)\end{array}$ & $\begin{array}{c}\text { Extreme air } \\
\text { temperature range } \\
\left({ }^{\circ} \mathrm{C}\right)\end{array}$ & $\begin{array}{c}\text { Estimate of antual } \\
\text { degree days above } 0^{\circ} \mathrm{C} \\
\text { (based on mean air } \\
\text { temperatures) }\end{array}$ \\
\hline $\begin{array}{l}\text { High Arctic } \\
\text { Low Arctic }\end{array}$ & 2 to & -34 to +5 & -60 to +20 & $50-350$ \\
$\begin{array}{l}\text { Sub-Antarctic } \\
\text { Maritime Antarctic }\end{array}$ & 6 tol2 & -36 to +11 & -10 to +25 & $600-900$ \\
Continental Antarctic & 1 to 4 & -2 to +8 & -45 to +15 & $700-1700$ \\
- coastal & 0 to & -12 to +2 & -40 to +10 & $6-100$ \\
- inland & 0 & -30 to -3 & $<-80$ to -5 & 0
\end{tabular}

environmental variation relative to other biogeographical regions in both the Antarctic and the Arctic (table 2). In particular this means that there is a relatively small difference between the warmest and coolest months - across all subAntarctic islands the warmest monthly mean temperature is only c. $7-8^{\circ} \mathrm{C}$, while only those south of the PFZ (i.e., South Georgia and Heard Island) have monthly minima (slightly) below $0^{\circ} \mathrm{C}$ (Convey 1996a, Danks 1999). At the microhabitat level relevant to most biota, this thermal damping becomes even more apparent, with temperatures generally remaining positive year-round. Unlike the highly seasonal tundra ecosystems of the Arctic, permafrost is not present in the sub-Antarctic. An important biological consequence of these thermal regimes is that the invertebrate faunas of these ecosystems, in particular, have much reduced seasonal structure in their activity patterns and life histories (Convey 1996a, Davies et al. 2007). The relatively low latitude of the sub-Antarctic islands (between c. $47^{\circ} \mathrm{S}$ and $54^{\circ} \mathrm{S}$, well north of the Antarctic (ircle) also results in a longer growing season than is the case at higher latitudes (table 2), although their typically high cloud cover also reduces instantaneous radiation receipt. The islands also lie within the cyclonic belt of the Southern Ocean, experiencing typically high average wind speeds and precipitation levels.

\section{BIODIVERSITY}

The differences between levels of terrestrial biodiversity in the Arctic and sub-Antarctic are striking (tables 3 and 4), even in comparison with the environmentally much more extreme and also isolated High Arctic Svalbard and Franz Josef archipelagoes at approaching $80^{\circ} \mathrm{N}$. While there are about 900 species of vascular plants in the Arctic there are only two on the Antarctic continent and a maximum of 40 on any single sub-Antarctic island (table 3). Likewise, the sub-Antarctic has no native land mammals, against the Arctic's 48 species. It is clear that the oceanic and atmospheric isolation of Antarctica and the sub-Antarctic (Barnes et al. 2006), in contrast with the continuous southwards continental connection of much of the Arctic, has been an important driver of the differences seen. Despite the apparent ease of access to much of the Arctic, a relatively low number of anthropogenically-introduced alien vascular plants or invertebrates are known at locations such as Svalbard (Rønning 1996, Coulson 2007), in comparison with the c. 200 species introduced to the sub-Antarctic by human activity over only the past two centuries or so (Frenot et al. 2005; table 5). This apparent contradiction may be explained because many of the sub-Antarctic "aliens" are cosmopolitan northern hemisphere and boreal "weeds" that have had greater opportunity to reach polar latitudes since deglaciation in the north than the south, either by natural means or during earlier phases of post-Pleistocene human colonisation. 
TABLE 3

Levels of species diversity of four of the better-known groups of biota across the sub-Antarctic islands

\begin{tabular}{lcccc}
\hline & $\begin{array}{c}\text { Higher } \\
\text { Plants }\end{array}$ & $\begin{array}{c}\text { Insects (not } \\
\text { Collembola) }\end{array}$ & Seabirds & Land birds \\
\hline South Georgia & 25 & 21 & 26 & 2 \\
Marion & 23 & 19 & 27 & 1 \\
Prince Edward & 21 & 18 & 28 & 1 \\
Crozet & $>19$ & $>44$ & $>33$ & 2 \\
Kerguelen & 30 & 27 & 33 & 3 \\
Heard & 10 & 11 & 18 & 1 \\
McDonald & 5 & 6 & 9 & 1 \\
Macquarie & 40 & 20 & 23 & 0 \\
\hline
\end{tabular}

TABLE 4

Species diversity in some of the main representative terrestrial groups of the sub-Antarctic biogeographical zone, in comparison with three Arctic locations ${ }^{1}$

\begin{tabular}{|c|c|c|c|c|}
\hline Group & Sub-Antarctic & High Arctic (Svalbard) & $\begin{array}{c}\text { High Arctic } \\
\text { (Franz Josef Land) }\end{array}$ & Greenland \\
\hline Rotifera & $>59$ & 154 & & \\
\hline Tardigrada & $>34$ & 83 & & \\
\hline Nematoda & $>22$ & 111 & & \\
\hline Platyhelminthes & 4 & 10 & & \\
\hline Annelida (Oligochaeta) & 23 & 34 & & \\
\hline Mollusca. & $3 / 4$ & 0 & & 2 \\
\hline Crustacea (non-marine) & 44 & 33 & & 65 \\
\hline Insecta & 210 & 237 & & 631 \\
\hline Collembola & $>30$ & 60 & & 41 \\
\hline Araneida & 20 & 19 & & 60 \\
\hline Acarina (free-living) & 140 & 127 & & 127 \\
\hline Myriapoda & 3 & 0 & & 1 \\
\hline Mammalia & 0 & 3 & 2 & 8 \\
\hline Aves & 0 & 17 & 6 & 39 \\
\hline Flowering plants & 0 & 164 & 57 & 515 \\
\hline Bryophytes & 26 & 373 & 150 & 612 \\
\hline Lichens & 150 & 597 & $>100$ & 950 \\
\hline
\end{tabular}

I Data sources: Svalbard - Barr (1995), Elvebakk \& Hertel (1996), Frisvoll \& Elvebakk (1996), Rønning (1996), Coulson \& Resferh (2004), Coulson (2007); Franz Josef Land - Barr (1995); Greenland - Jensen \& Christensen (2003); sub-Antarctic-Convey (2007a).

TABLE 5

The recorded occurrence of alien non-indigenous species across Antarctic biogeographical zones ${ }^{1}$

\begin{tabular}{|c|c|c|c|c|c|c|c|c|c|c|c|}
\hline & 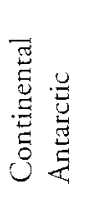 & 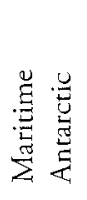 & 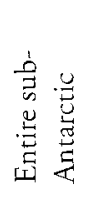 & 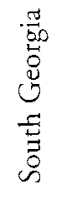 & 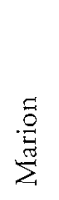 & 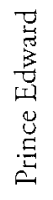 & 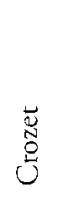 & 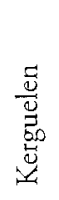 & 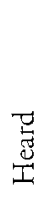 & 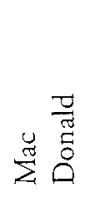 & 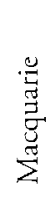 \\
\hline Dicotyledons & 0 & 0 & 62 & 17 & 6 & 2 & 40 & 34 & 0 & 0 & 2 \\
\hline Monocotyledons & 1 & 2 & 45 & 15 & 7 & 1 & 18 & 34 & 1 & 0 & 1 \\
\hline Pteridophytes & 0 & 0 & 1 & 1 & 0 & 0 & 1 & 1 & 0 & 0 & 0 \\
\hline Total non-indigenous plants & 0 & 2 & 108 & 33 & 13 & 3 & 59 & 69 & 1 & 0 & 3 \\
\hline Invertebrates & 0 & $2-5$ & 72 & 12 & 18 & 1 & 14 & 30 & 3 & 0 & 28 \\
\hline Vertebrates & 0 & 0 & 16 & 3 & 1 & 0 & 6 & 12 & 0 & 0 & 6 \\
\hline
\end{tabular}

1 Extracted from Frenot et al. (2005) and Convey (2007b); see also Greenslade (2006) for a detailed description of established and transient alien species, and species recorded only synanthropically, from sub-Antarctic Macquarie Island. 
Sub-Antarctic floras and faunas are typically disharmonic and do not include representatives of several taxonomic and functional groups common in lower latitudes. Sub-Antarctic plant communities do not include woody plants, and are dominated by herbs, graminoids and cushion plants. These floras also generally do not include species requiring insect pollination, other than possibly two little-known endemic orchid species from Macquarie Island, and pollinating insects likewise do not form a component of the insect faunas (Convey et al. 2006a). Megaherbs are a striking element of the flora of many islands, being an important structuring force within habitats, and a major contributor of biomass (Meurk et al. 1994a, Mitchell et al. 1999, Fell 2002, Shaw 2005, Convey et al. 2006a). Several different plant families are represented by regional and endemic megaherb taxa (Apiaceae - Stilbocarpa, Brassicaceae - Pringlea, Asteraceae - Pleurophyllum). Large tussock grass species (Poaceae Poa and Parodiochlod) also provide a dominant structural presence. These plant growth forms present an unusual combination of morphological and life history characteristics (Convey et al. 2006a), that includes high primary production and biomass allocation to both leaf and underground storage tissue, seed mass and seed output. Their dominance on sub-Antarctic islands is thought to have been encouraged by the absence of natural vertebrate herbivores (Meurk et al. 1994a, Mitchell et al. 1999), while also having other adaptive benefits relating to the harvesting and focusing of low light levels and aerosol nutrients (Wardle 1991, Meurk et al. 1994b). The recent anthropogenic introduction of vertebrate herbivores to most sub-Antarctic islands has led to considerable and negative impacts on megaherb-based communities (Frenot et al. 2005, 2007, Shaw et al. 2005, Convey et al. 2006b).

Across the sub-Antarctic there are no native land mammals, reptiles or amphibians and very few non-marine birds. The latter are limited to three species of freshwater duck (two on South Georgia, one on Îles Kerguelen and Crozet), a single passerine endemic on South Georgia (Anthus antarcticus Cabanis, 1884 the South Georgia Pipit), and two scavenging sheathbills. Although outside the scope of this review, many of the islands are of considerable conservation importance, hosting globally significant populations of marine vertebrates (Woehler et al. 2001). The most abundant macroscopic terrestrial invertebrates of the sub-Antarctic are the micro-arthropod mites and springtails, with population densities in tens to hundreds of thousands of individuals $\mathrm{m}^{-2}$. There are also enchytraeids, earthworms, tardigrades, nematodes, spiders, beetles, flies and moths, with smaller representation of some other insect groups (Gressitt 1970, Convey 2007a). Few of these invertebrates are thought to be true herbivores, with the exception of some beetles and the moths, although detailed autecological studies are typically lacking. Spiders and a small number of carabid, dytiscid and staphylinid beetles are carnivorous but, other than these, macro-invertebrate predators are absent, and predation levels are thought to be insignificant (although this is a generally untested assumption). The introduction of carabids to parts of South Georgia and Îles Kerguelen is leading to extensive changes to local community structure, which threaten the continued existence of some indigenous and/or endemic invertebrates (Ernsting et al. 1995, Frenot et al. 2005, 2007). Regional warming has also been predicted to rapidly increase the impact of certain indigenous predators, such as the diving beetle Lancetes angusticollis (Curtis, 1839) in lakes on South Georgia (Arnold \& Convey 1998). Despite the preponderance of detritivores, decay processes are slow in most habitats. Detailed studies on Marion Island have indicated that indigenous detritivorous invertebrates are currently insufficient to overcome a bottleneck in the decomposition cycle (Slabber \& Chown 2002).

Although sub-Antarctic ecosystems are more diverse and complex than those of more extreme Antarctic latitudes (Convey 2007a), they remain simple in global terms, commonly lacking or with low diversity in specific taxonomic or biological functional groups. Therefore they are thought to lack the functional redundancy that is typical of more diverse ecosystems. This lack of indigenous diversity raises the possibility of new colonists (natural or anthropogenicallyassisted) filling previously unoccupied ecological niches. Such colonists could include new trophic functions or levels, and would inevitably change fundamentally the structure and function of trophic webs. Responses of indigenous biota to such changes and the advent of new competitors and predators will be constrained by their typically "adversityselected" life history strategies (Convey 1996b), which primarily confer abilities to survive abiotic environmental extremes, while competitive abilities are very poorly developed. These native species and communities appear to be particularly vulnerable to predation from invading taxa, as native invertebrate predators are generally of little or no significance (Ernsting et al. 1995, Convey 1996b, 2003, Frenot et al. 2005, Convey et al. 2006b).

\section{BIOGEOGRAPHIC PATTERNS AND DRIVERS}

The widely varying geological and glaciological histories of the sub-Antarctic islands provide the template on which their patterns of biodiversity and biogeography have evolved. Understanding of these patterns relies on resolution of three fundamental problems: (1) many areas have not been systematically explored, even on such defined and small land masses; (2) many of the less charismatic taxa have not received basic survey attention even for those that have, and comprehensive and up-to-date databases of the distributions of sub-Antarctic species do not exist; (3) both robust systematic studies and modern molecular phylogenies are absent for many taxa, while very few taxonomists or funding agencies have resources to devote to the biota of this region. Although a number of recent compilations are available either for specific islands or specific taxonomic groups, both of published records and of newly (re-)examined material (Pugh 1993, Bednarek-Ochyra et al. 2000, Øvstedal \& Smith 2001, Pugh et al. 2002, Pugh \& Scott 2002, Seppelt 2004, Chown et al. 2006, Greenslade 2006, Ochyra et al. in press), these factors mean that any biogeographic assessments inevitably rely on incomplete data and, hence, are constrained to weak approaches to phylogeographic analyses (Chown \& Convey 2006, 2007). For instance, the closest relatives of many prominent endemic sub-Antarctic invertebrate taxa (the Ectemnorhinus-group weevils and Pringleophaga spp. tineid moths) remain unconfirmed except on the basis of conventional systematics (Jeannel 1964, Kuscbel \& Chown 1995). Using the available data, Chown etal. (1998) identified that several well-known biodiversity drivers were important across the Southern Ocean islands, including area, distance from sources, temperature, richness of other biotic groups and human occupancy (see also Selmi \& Boulinier 2001). 
Perhaps the most fundamental challenge relating to subAntarctic terrestrial biogeography is that of separating the two influences of dispersal and vicariance in determining the current distributions across the region. This dichotomy is superimposed on a second area of controversy, that of whether the entire sub-Antarctic region can be regarded as a single biogeographic province (the "Insulantarctic" hypothesis - Udvardy 1987), or whether a "multiregional" hypothesis is more appropriate (i.e., that there are different provinces of the Southern Ocean, with different origins, history and sources of biota - Kuschel \& Chown 1995 , Craig et al. 2003). The debate essentially rests on whether all the islands share enough of their biotas to form a single biogeographic entity (as proposed by Holdgate 1960, Skottsberg 1960, Udvardy 1987, van de Vijver \& Beyens 1999), or whether there are sufficient regional differences simply to require that each is most appropriately linked to the Southern Hemisphere continent to which they are closest (Gressitt 1970, Smith 1984, Morrone 1998, Cox 2001, McDowall 2005).

In many respects this is a sterile debate (Chown \& Convey 2006), with the conclusion drawn depending to a large extent on the particular taxonomic group under consideration (Greve et al. 2005). The latter authors present evidence, based on the degree of nestedness shown in distributions of species and genera of different groups, that illustrates instances of support for both the Insulantarctic and multiregional hypotheses. Distribution patterns of groups that are weak dispersers are strongly influenced by regional source pools, in particular the most adjacent continents and large islands within archipelagoes (Morrone 1998), whilst those of mobile taxa (i.e., those with dispersing life stages) are more uniform (Barrat \& Mougin 1974). A number of very different organisms (oribatid mites Halozetes, springtails - Cryptopygus, grass - Deschampsia, herb - Acaena) share circum-sub-Antarctic distributions (Bergstrom et al. 2006; illustrated in fig. 1 for Acaena), which are most parsimoniously explained by dispersal processes acting across the entire region. However, there remain important anomalies. For instance, bryophytes are widely regarded as efficient dispersers, producing a range of spores and other propagules (Longton 1988). Of the terrestrial biota of the Antarctic continent bryophytes are the only major group present to show the very low levels of species endemism that should be associated with the widely assumed pattern of recent (post-Pleistocene glaciation) colonisation (Chown \& Convey 2006, Peat et al. 2007, Convey et al. in press b). However, while Muñoz et al. (2004) proposed that sub-Antarctic bryophyte distribution patterns support an hypothesis of dispersal by wind across the region, nestedness analysis suggested little difference was present in reality between them and what are highly

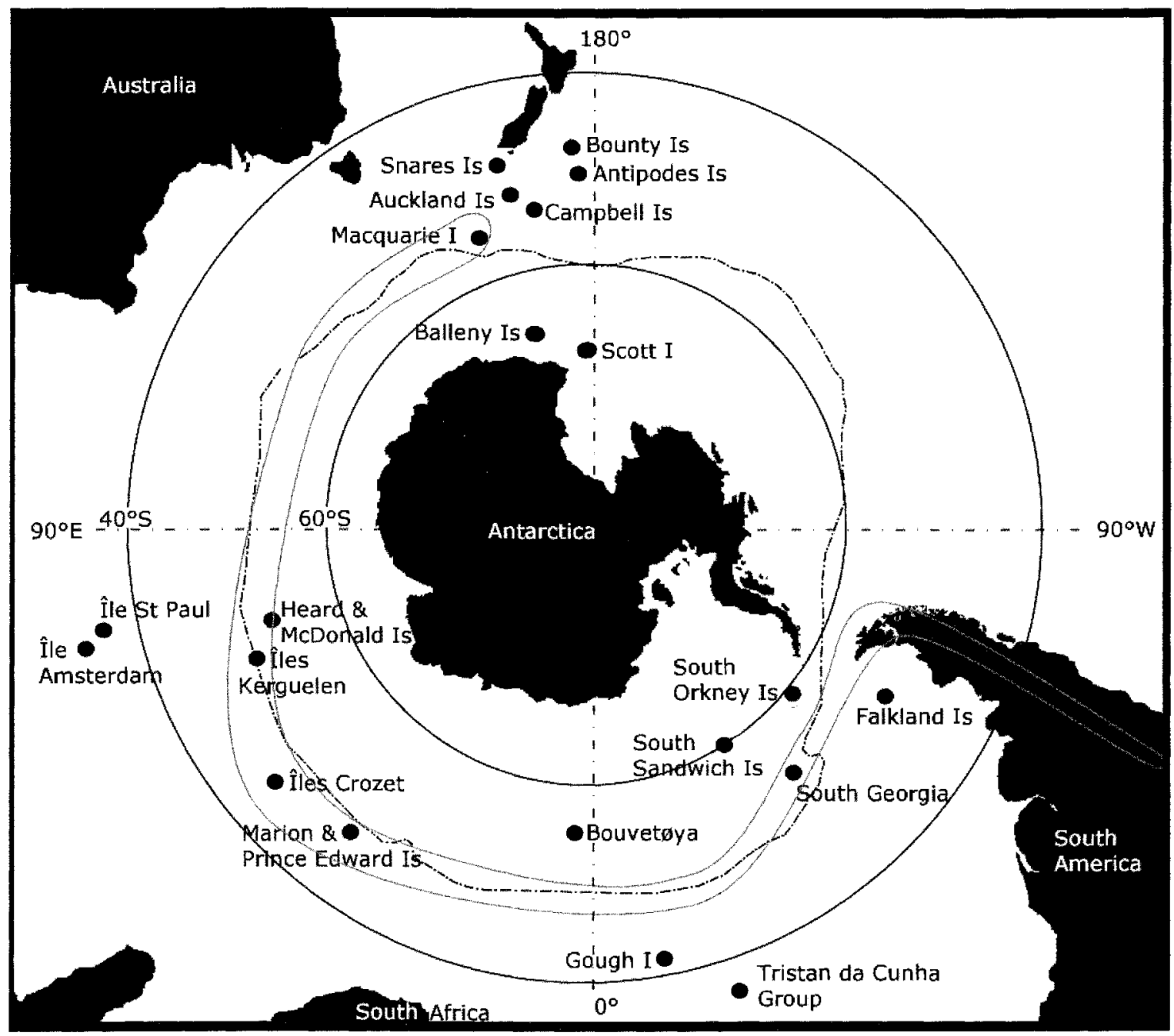

FIG. 1 - The circum-Antarctic distribution of the herb Acaena (reproduced from Bergstrom et al. 2006). 
regionalised vascular plant distributions (Greve et al. 2005). This contradiction may relate in part to the use of imperfect taxonomy in the earlier study, but it may also illustrate that long-range bryophyte dispersal may not be as effective as is commonly assumed.

While the majority of islands are too young to carry a signal of their biological history on a Gondwana-breakup timescale, the older islands of South Georgia and Kerguelen have the potential to do so. However, terrestrial fossil evidence is generally sparse in the sub-Antarctic, other than fossil floras that are known from islands of the Kerguelen Plateau (Chastain 1958, Quilty \& Wheller 2000; Truswell et al. 2005) and a single example of fossil wood, dating from the Early Cretaceous, from South Georgia (Gordon 1930). Nothing can be concluded about continuity between fossil and contemporary biota. Other studies have inferred signals of ancient regional origin from contemporary distributions (Brundin 1966, Darlington 1970, McInnes \& Pugh 1998, Craig 2003). An example of this is provided by the Collembola genus Setanodosa, known only from South Georgia in the Antarctic/sub-Antarctic region, and from South America, South Africa and Australia. The implication is of a Gondwanan distributional link, at least between the major continents, although in the absence of molecular phylogenetic studies it is not currently possible to differentiate between this and more recent dispersal in explaining the presence on South Georgia.

A single molecular phylogenetic study of Scotia Arc Diptera has proposed the continuous presence of an evolutionary lineage of chironomid midge on the South Georgian microplate over a timescale dating from its separation from southern South America and the Antarctic Peninsula (Allegrucci et al. 2006), 40-50 ma. Also based on molecular phylogenetic analyses, Stevens et al. (2006) inferred recent $(<2 \mathrm{ma})$ dispersal/colonisation events of springtail (Cryptopygus) species between some sub-Antarctic islands, with a close association between estimated times of divergences based on a molecular clock and proposed geological ages of islands. On a more recent timescale, local isolation of populations by Pleistocene glacial cycles has been an important evolutionary force driving differentiation processes (Marshall \& Convey 2004, Mortimer \& Jansen van Vuuren 2007). These studies demonstrate the potential for the application of such techniques to shed light on the biogeographical history and structure of the sub-Antarctic, and rapid advances are now being made in this field.

Ignoring for the moment the direct influence of humans, there are three broad mechanisms that might facilitate natural colonisation and dispersal processes into and within the Antarctic (Gressitt 1970, Hughes et al. 2006). These are transport in air, water or via a third-party vector (other organisms, debris). Wind is well known to play a major role in the colonisation of isolated environments by smaller organisms, particularly those with an appropriate stressresistant life stage. In a sub-Antarctic and Antarctic context, this applies to bryophytes, lichens, many microbes and certain invertebrates such as rotifers, tardigrades and some freshwater crustaceans and terrestrial arthropods (LaybournParry \& Marchant 1992, Marshall 1996, Muñoz et al. 2004, Greve et al. 2005). However, it is also currently thought that long-distance aerial dispersal is inappropriate for other elements of the sub-Antarctic and Antarctic faunas, such as most terrestrial arthropods and molluscs (Pugh \& Scott 2002, Pugh 2003), while it may only operate on relatively short scales of distance for others such as Collembola (Hawes et al. 2007b). Other than the study of Marshall (1996), which relates to a maritime Antarctic island location, there are no recent studies quantifying the frequency or magnitude of aerobiological transfer into the Antarctic region. However, it is clear from the occasional arrivals of known migratory moth species that aerial transfer to the sub-Antarctic islands does occur (Greenslade et al. 1999, Convey 2005).

Given the scale of physical isolation of the sub-Antarctic islands, and the typical meteorological conditions and sea states experienced at their latitudes in the Southern Ocean, transport in water or on the water surface would seem unlikely, and there are no confirmed instances. However, some groups well-represented in sub-Antarctic terrestrial faunas, such as the ameronothroid mites and some isotomid and hypogastrurid springtails, are known to show very wide ecophysiological tolerances and can survive long periods in or on the surface of seawater (Strong 1967, King et al. 1990 , Davenport \& MacAlister 1996, Coulson et al. 2002, Marshall \& Convey 2004, Hawes et al. 2007a). This mechanism is likely to underlie dispersal of marine littoral species, some of which also then occupy supralittoral habitats. There are also no demonstrations of transfer of terrestrial species into or within the Antarctic region on floating debris, although the possibility has been recognised and examples relating to marine biota exist (Barnes \& Fraser 2003, Hughes et al. 2006).

Finally, the potential route of zoochory (transport attached to other animals, usually vertebrates) has been recognised (Pugh 1997) although, again, there are few confirmed examples of this occurring in the Antarctic or sub-Antarctic. Earlier reports are limited to algae and microbiota (Gressitt 1964, Schlichting et al. 1978). Recently, Krivolutsky et al. (2004) have carried out a more detailed study of the arthropod load carried by a range of Antarctic bird species collected on the South Shetland Islands and Antarctic continent. They report several species of mite and a single spider being collected from the plumage of these birds, none of which were apparently species resident at the collection locations. Perhaps most surprisingly, species thought to be terrestrial were collected from the plumage of penguins, including from Emperor Penguins that do not come into direct contact with terrestrial habitats at any point in their life-cycle. In a sub-Antarctic context, the most plausible bird vector species are those that routinely migrate to other continents (skuas, gulls and sheathbills) (Barnes et al. 2006). In some cases, some invertebrates and plant and microbial propagules may possess appropriate resistance features to permit survival of passage through vertebrate guts (Frenot et al. 2005), such as those of seals (Pugh 1994) and subAntarctic ducks (T. Martin, pers. comm.).

\section{HUMAN IMPACTS}

Antarctica and the isolated lands of the Southern Ocean are uniquein never having had an indigenous human population or a long-term history of human residence and impact. The short human history in the region commenced with early exploring voyages into the Southern Ocean, and with the discoveries of the isolated peri-Antarctic islands, within the past two to three centuries. The Antarctic Peninsula (West Antarctica) was first sighted in 1820 , and probably landed on in 1821, and humans first set foot on East Antarctica in 1895 (Headland 1989). Direct human impacts so far have largely been restricted to Southern Ocean marine ecosystems 
(sealing, whaling, fishing) and sub-Antarctic terrestrial ecosystems (Knox 1994, Frenot et al. 2005, 2007, Convey et al. 2006b, in press a). Indirectly, human activities are also impacting the Antarctic through the pervasive presence of persistent organic and inorganic pollutants (Bargagli 2005), and the processes of climatic change consequential on global warming and stratospheric ozone depletion (Walther et al. 2002, Convey 2003, 2006). Human contact with Antarctica is currently growing rapidly (Navareen et al. 2001, Frenot $e t$ al. 2005, COMNAP 2006, IAATO 2006). Identifying and responding to the requirements for conservation of Antarctic ecosystems are high profile issues both within the Committee for Environmental Protection of the Antarctic Treaty System, and within the sphere of public interest generated through the media and activities of non-governmental organisations.

Parts of the Antarctic region are currently experiencing rapid change in a number of climatic variables - most obviously temperature, but also in precipitation patterns and amounts, and cloudiness. Some of the most rapid temperature increases seen worldwide over the past 50 years have been documented along the western Antarctic Peninsula and associated Scotia Arc archipelagoes (King et al. 2003, Vaughan et al. 2003, Turner et al. 2005). Although the only sub-Antarctic island included in this region is South Georgia, the maritime Antarctic island archipelagoes are also included; some authors group these with the more strictly defined sub-Antarctic islands. Warming trends have also been identified at several other sub-Antarctic locations (Jacka \& Budd 1998, Marion Island - Smith \& Steenkamp (1990), Smith (2002), Îles Kerguelen - Frenot et al. (1997), Macquarie Island - Tweedie \& Bergstrom (2000)). At finer, seasonal, timescales as yet there are no consistent seasonal patterns across the sub-Antarctic islands. Thus, Macquarie Island appears to be warming most during late summer and early autumn (Adamson et al. 1988), although this was not confirmed by Tweedie \& Bergstrom (2000). Highest warming rates are seen on Marion Island during late winter and early summer (Smith \& Steenkamp 1990). There is some evidence that Îles Kerguelen are warming more in summer (Allison \& Keage 1986; but see also Frenot et al. 1997 who reported no seasonal difference in a longer dataset). Precipitation patterns are also changing on some islands, with reports of both increases on Macquarie Island (C. Tweedie, D. Doley \& D. Bergstrom unpublished data), and decreases on Marion Island and Îles Kerguelen (Smith \& Steenkamp 1990, Frenot et al. 1997, Chown \& Smith 1993, Smith 2002, Chapuis et al. 2004). In concert with these changes, rapid rates of glacial retreat have taken place on the heavily glaciated South Georgia and Heard Island (Gordon \& Timmis 1992, Pugh \& Davenport 1997, Kiernan $\&$ McConnell 2002). This process has various consequences, including exposing new ground for colonisation, altering (generally increasing) water input to terrestrial habitats, and opening up overland routes for movement of terrestrial biota into previously isolated regions. The latter is of particular significance for South Georgia, as it permits the movement of introduced rats and reindeer into new areas, with highly deleterious consequences for native ecosystems (Frenot et al. 2005, Convey et al. 2006b).

The consequences of changes in two major environmental variables (temperature, water availability) have formed a particular focus in studies of climate change responses in the Antarctic, although few such studies have focused specifically on the sub-Antarctic islands. The widely reported warming trends have led to a range of general predictions (Convey
2003), including increases in the rates of colonisation on both local and long-distance scales, increased terrestrial diversity and biomass, and increased trophic complexity (through the inclusion or greater functional representation of higher trophic levels). As yet, few studies have addressed these processes in a sub-Antarctic context, although environmental manipulation studies on South Georgia (Smith 2001) have demonstrated local colonisation and community development potential through dormant propagule banks. Negative consequences from environmental changes are also clearly possible, and one such might be a reduction in local extent of Azorella cushion plants on Marion Island, influenced by the trend of reduced precipitation recorded on this island (le Roux et al. 2005).

Human contact with the sub-Antarctic over the past two centuries or so has led to the introduction of over 200 known non-indigenous species (table 5; Frenot et al. 2005). The majority of these are vertebrates or flowering plants, although an increasing number of invertebrates are now being recognised (Greenslade 2006). However, it remains the case that the quality of data available varies widely between the sub-Antarctic islands and also between the major higher taxonomic groups. Thus, while the presence of non-indigenous flowering plants is quite well known throughout the region, little or no attention has been given to bryophytes or lichens. Likewise, detailed data are unavailable for most microarthropod and other microfaunal groups (nematodes, tardigrades, rotifers), to the extent that even authoritative lists of indigenous species are not available in many cases, rendering the identification of non-indigenous species problematic (although see Greenslade (2006) for Macquarie Island). However, it is clear that some major sub-Antarctic islands remain relatively unaffected by the establishment of non-indigenous species (particularly Prince Edward and Heard islands). The value and conservation status of these two islands has been recognised by, in the former case, the operation of a detailed and proscriptive management plan (Anonymous 1996), and in the latter by the awarding of World Heritage Site status (see Chown et al. 2001). However, other sub-Antarctic islands have been and continue to be heavily impacted (particularly South Georgia, Îles Kerguelen, Macquarie Island). On these islands there have been well-documented examples of drastic ecosystem impacts, mainly relating to rodent or cat predation of indigenous birds, mammalian grazing, and the spread of cosmopolitan weed plant species (see Frenot et al. (2005) for review). Because some of the impacted species and ecosystems are very restricted globally, damage to these islands presents an important threat to regional and global biodiversity. Although natural colonisation of the species-poor sub-Antarctic ecosystems is an ongoing process, the importance of anthropogenic activity in facilitating introduction and establishment must also be recognised. Studies on sub-Antarctic Marion Island and South Atlantic Gough Island suggest that the frequency of anthropogenic introduction outweighs that of natural processes by up to two orders of magnitude or more (Gaston et al. 2003, Gremmen \& Smith 2004, Pugh 2004). After only two centuries of contact, anthropogenic introductions now account for over $50 \%$ of angiosperm biodiversity on South Georgia and Îles Kerguelen. Non-indigenous species that become invasive are now presenting major challenges for ecosystem management, and in most cases no simple solutions are available. Even in cases where eradication of introduced species is practicable (most obviously, grazing 
large mammals and cats), it is not clear that eradication will simply lead to ecosystem recovery.

\section{CONCLUSIONS}

A number of formulations or definitions of the sub-Antarctic are in more or less common use in the literature. The definition used in the current paper, based on climatic similarities and the common absence of woody plants, identifies a discrete set of isolated Southern Ocean islands at latitudes of c. $47^{\circ} \mathrm{S}$ to $54^{\circ} \mathrm{S}$, all lying relatively close to the oceanic PFZ. Terrestrial ecosystems on the majority of these islands are plainly post-Gondwanan in origin, as most islands formed long after Gondwana-breakup. A few (particularly South Georgia) provide evidence of ancient biogeographical signals consistent with events during the final breakup of Gondwana. The extreme isolation and generally poor environmental conditions experienced in this region are indicated by the overall low levels of biodiversity present on all islands, and their disharmonic taxonomic composition. Contemporary biogeographical patterns vary between groups of biota or habitats, with examples supporting both Insulantarctic and multi-regional hypotheses for their origin, and strong indications of both the importance of wind and other means oflong-distance dispersal as well as of more local evolutionary radiation. Recent human impacts (climate change, introduced species) are already strong, and may far outweigh natural dispersal processes, presenting major management and conservation challenges.

\section{ACKNOWLEDGEMENTS}

The organisers of the sub-Antarctic Forum held in Hobart (July 2006) are warmly thanked for the opportunity to participate in the meeting. Two anonymous reviewers are thanked for their comments. This paper forms an output of the BAS BIOPEARL and SCAR Evolution and Biodiversity in Antarctica research programmes.

\section{REFERENCES}

Adamson, D.A., Selkirk, P.M., Price, D.M. \& Ward, N. 1995: Uplift of the Macquarie Ridge at Macquarie Island: Pleistocene evidence from raised beaches and topography. Climate succession and glacial history of the Southern Hemisphere over the past five million years. ANARE Research Notes 94: 3-5.

Adamson, D.A., Whetton, P. \& Selkirk, P.M. 1988: An analysis of air temperature records for Macquarie Island: decadal warming, ENSO cooling and southern hemisphere circulation patterns. Papers and Proceedings of the Royal Society of Tasmania 122: 107-112.

Allegrucci, G., Carchini, G., Todisco, V., Convey, P. \& Sbordoni, V. 2006: A molecular phylogeny of Antarctic Chironomidae and its implications for biogeographical history. Polar Biology 29: 320-326.

Allison, I.F. \& Keage, P.L. 1986: Recent changes in the glaciers of Heard Island. Polar Record 23: 255-271.

Anonymous 1996: Prince Edward Islands Management Plan. Department of Environmental Affairs and Tourism, Pretoria.

Arnold, R.J. \& Convey, P. 1998: The life history of the world's most southerly diving beetle, Lancetes angusticollis (Curtis) (Coleoptera: Dytiscidae), on sub-Antarctic South Georgia.
Polar Biology 20: 153-160.

Bargagli, R. 2005: Antarctic Ecosystems: Environmental Contamination, Climate Change and Human Impact. Ecological Studies, Vol. 175, Springer, Berlin, xv +395 Pp.

Barnes, D.K.A. \& Fraser, K.P.P. 2003: Rafuing by five phyla on man-made flotsam in the Southern Ocean. Marine Ecology Progress Series 262: 289-291.

Barnes, D.K.A., Hodgson, D.A., Convey, P., Allen, C. \& Clarke, A. 2006: Incursion and excursion of Antarctic biota: past, present and future. Global Ecology and Biogeography 15: $121-142$

Barr, S. (ed.) 1995: Franz Josef Land. Norsk Polarinstitutt, Tromso: $175 \mathrm{pp}$.

Barrat, A. \& Mougin, J.L. 1974: Donneés numériques sur la zoogéographie de l'avifane Antarctique et Subantarctique. Comité Nationale Français des Recherches Antarctiques 33: $1-18$.

Bednarek-Ochyra, H., Väňa, J., Ochyra, R. \& Smith, R.I.L. 2000: The Liverwort Flora of Antarctica. Institute of Botany, Polish Academy of Sciences, Cracow: xvi $+236 \mathrm{pp}$.

Bergstrom, D., Hodgson, D.A. \& Convey, P. 2006: 2. The physical setting of the Antarctic. In Bergstrom, D.M, Convey, P. \& Huiskes, A.H.L. (eds): Trends in Antarctic Terrestrial and Limnetic Ecosystems: Antarctica as a Global Indicator. Springer, Dordrecht: pp 15-33.

Brundin, L. 1966: Transantarctic relationships and their significance as evidenced by chironomid midges. Svenska Vteneskapsakademie Handlunge 11: 1-472.

Chapuis, J.L., Frenot, Y. \& Lebouvier, M. 2004 : Recovery of native plant communities after eradication of rabbits from the subantarctic Îles Kerguelen, and influence of climate change. Biological Conservation 117: 167-179.

Chastain, A. 1958: La flore et la vegetation des Îles de Kerguelen. Memoires du Museum National d'Histoire Naturelle, Series $B$ 9: 1-136.

Chown, S.L. \& Convey, P. 2006: 4. Biogeography. In Bergstrom, D.M, Convey, P. \& Huiskes, A.H.L. (eds): Trends in Antarctic Terrestrial and Limnetic Ecosystems: Antarctica as a Global Indicator. Springer, Dordrecht: pp. 55-69.

Chown, S.L. \& Convey, P. 2007: Spatial and temporal variability across life's hierarchies in the terrestrial Antarctic. Philosophical Transactions of the Royal Society of London, series $B$, doi: $10,1098 / 1866.2006 .1949$.

Chown, S.L. \& Smith, V.R. 1993 : Climate change and the short-term impact of feral house mice at the sub-Antarctic Prince Edward Islands. Oecologia 96: 508-516.

Chown, S. L., Greenslade, P. \& Marshall, D. J. 2006: Terrestrial invertebrates of Heard Island. In Green, K. \& Woehler, E.J. (eds): Heard Island: Southern Ocean Sentinel. Surrey \& Beatty, Chipping Norton: pp. 91-104.

Chown, S.L., Gremmen, N.J.M. \& Gaston, K.J. 1998: Ecological biogeography of southern ocean islands: species-area relationships, human impacts, and conservation. American Naturalist 152: 562-575.

Chown, S.L., Rodrigues, A.S.L., Gremmen, N.J.M. \& Gaston, K.J. 2001: World Heritage status and the conservation of Southern Ocean islands. Conservation Biology 15: 550-557

COMNAP 2006: Antarctic Operations. www.comnap.aq/ operations (accessed March 2007).

Convey, P. 1996a: Overwintering strategies of terrestrial invertebrates from Antarctica - the significance of flexibility in extremely seasonal environments. European Journal of Entomology 93: 489-505.

Convey, P. 1996b: The influence of environmental characteristics on the life history attributes of Antarctic terrestrial biota. Biological Reviews 71: 191-225.

Convey, P. 2003: Maritime Antarctic climate change: signals from terrestrial biology. Antarctic Research Series 79: 145-158.

Convey, P. 2005: Recent lepidopteran records from sub-Antarctic 
South Georgia. Polar Biology 28: 108-1 10.

Convey, P. 2006: 12. Antarctic climate change and its impacts on terrestrial ecosystems. In Bergstrom, D.M., Convey, P. \& Huiskes. A.H.L. (eds): Trends in Antarctic Terrestrial and Limnetic Ecosystems: Antarctica as a Global Indicator, Springer, Dordrecht: pp. 253-272.

Convey, P. 2007a: Antarctic ecosystems. In Levin, S.A. (ed), Encyclopedia of Biodiversity, 2nd Edition, Elsevier, San Diego (in press).

Convey, P. 2007b: Non-native species in the Antarctic terrestrial environment. "Aliens in Antarctica" Workshop Proceedings, Gateway Antarctica, Christchurch, New Zealand (in press).

Convey, P., Barnes, D.K.A., Clark, M.S. Dominic A. Hodgson, D.A. \& Peck, L.S. In press a: An holistic approach to understanding the biological impacts of climate change: Antarctica as a planetary warning system. Inside Agriculture.

Convey. P., Chown, S.L., Wasley, J. \& Bergstrom, D.M. 2006a: 6. Life history traits. In Bergstrom, D.M., Convey, P. \& Huiskes, A.H.L. (eds): Trends in Antarctic Terrestrial and Limnetic Ecosystems: Antarctica as a Global Indicator, Springer, Dordrecht: pp. 101-127.

Convey, P., Frenot, F., Gremmen, N. \& Bergstrom, D. 2006b: 10. Biological invasions. In Bergstrom, D.M., Convey, P. \& Huiskes, A.H.L. (eds): Trends in Antarctic Terrestrial and Limnetic Ecosystems: Antarctica as a Global Indicator, Springer, Dordrecht: pp. 193-220.

Convey, P., Gibson, J., Hillenbrand, C.-D., Hodgson, D.A., Pugh, P.J.A., Smellie, J.L. \& Stevens, M.I. In press b: Antarctic terrestrial life - challenging the history of the frozen continent? Biological Reviews.

Coulson, S.J. 2007: The terrestrial and freshwater invertebrate fauna of the High Arctic archipelago of Svalbard. Zootaxa 1448: $41-68$.

Coulson, S.J. \& Resfeth, D. 2004: The terrestrial and freshwater fauna of Svalbard (and Jan Mayen). In Prestrud, P., Strøm, H. \& Goldman, H.V. (eds): A Catalogue of the Terrestrial and Marine Animals of Svalbard. Norwegian Polar Institute, Trømso, Norway: pp. 57-122.

Coulson, S.J., Hodkinson, I.D., Webb, N.R. \& Harrison, J.A. 2002: Survival of terrestrial soil-dwelling arthropods on and in seawater: implications for trans-oceanic dispersal. Functional Ecology 16: 353-356.

Cox, C.B. 2001: The biogeographic regions reconsidered. Journal of Biogeography 28: 511-523.

Craig, D.A. 2003: Deconstructing Gondwana - words of warning from the Crozet Island Simuliidae (Diptera). Cimbebasia 19: $157-164$.

Craig, D.A., Currie, D.C. \& Vernon, P. 2003: Crozetia Davies (Diptera: Simuliidae): redescription of $C r$. crozetensis, $C r$. sequyi, number of larval instars, phylogenetic relationships and historical biogeography. Zootaxa 259: 1-39.

Danks, H.V. 1999: Life cycles in polar arthropods - flexible or programmed? European Journal of Entomology $\mathbf{9 6}$ 83-102.

Darlington, P.J. 1970: A practical criticism of Hennig-Brundin "phylogenetic systematics" and Antarctic biogeography. Systematic Zoology 19: 1-18.

Davenport, J. \& MacAlister, H.E. 1996: Environmental conditions and physiological tolerances of intertidal fauna in relation to shore zonation at Husvik, South Georgia. Journal of the Marine Biological Association 76: 985-1002.

Davies, L., Bouvet, S. \& Vernon, P. 2007: All-year reproduction and possible thermal melanism in Amblystogenium pacificum (Coleoptera: Carabidae) on the sub-Antarctic Ile de la Possesssion (Iles Crozet). Polar Biology 30: 253-260.

Dingwall P.R. (ed.) 1995: Progress in Conservation of the Subantarctic Islands. IUCN, Gland, xvi $+225 \mathrm{pp}$.

Elvebakk, A. \& Hertel, H. 1996: Part 6. Lichens. In Elvebakk, A.
\& Prestrud, P. (eds): A Catalogue of Svalbard Plants, Fungi and Cyanobacteria. Norwegian Polar Institute Skrifter 198. Norwegian Polar Institute, Tromsø: pp. 271-359.

Ernsting, G., Block, W., MacAlister, H. \& Todd, C. 1995: The invasion of the carnivorous carabid beetle Trechisibus antarcticus on South Georgia (subantarctic) and its effect on the endemic herbivorous beetle Hydromedion spasutum. Oecologia 103: 34-42.

Fell, D. 2002: Campbell Island, Land of the Blue Sunflower. Bateman, Auckland: 143 pp.

Frenot, Y., Chown, S.L., Whinam, J., Selkirk, P., Convey, P., Skotnicki, M. \& Bergstrom, D. 2005: Biological invasions in the Antarctic: extent, impacts and implications. Biological Reviews 80: 45-72.

Frenot, Y., Convey, P., Lebouvier, M., Chown, S.L., Whinam, J., Selkirk, P.M., Skotnicki, M. \& Bergstrom, D.M. 2007: Biological invasions: an environmental issue for Antarctica and the sub-Antarctic. "Aliens in Antarctica" Workshop Proceedings, Gateway Antarctica, Christchurch, New Zealand (in press).

Frenot, Y., Gloaguen, J.-C. \& Trehen, P. 1997: Climate change in Kerguelen Islands and colonization of recently deglaciated areas by Poa kerguelensis and $P$. annua. In Battaglia, B., Valencia, J. \& Walton, D.W.H. (eds): Antarctic Communities: Species, Structure and Survival. Cambridge University Press, Cambridge: pp. 358-366.

Frisvoll A.A. \& Elvebakk A. 1996: Part 2. Bryophytes. In Elvebakk, A. \& Prestrud, P. (eds): A Catalogue of Svalbard Plants, Fungi and Cyanobacteria. Norwegian Polar Institute Skrifter 198. Norwegian Polar Institute, Tromsø: pp 57-172.

Gaston K.J., Jones A.G., Hänel C. \& Chown S.L. 2003: Rates of species introduction to a remote oceanic island. Proceedings of the Royal Society of London, series B 270: 1091-1098.

Gladczenko, T.P. \& Coffin, M.F. 2001: Kerguelen Plateau crustral structure and basin formation from seismic and gravity data. Journal of Geophysical Research 18: 16583-16601.

Gordon, J.E. \& Timmis, R.J. 1992: Glacier fluctuations on South Georgia during the 1970 s and early 1980s. Antarctic Science 4: 215-226.

Gordon, W.T. 1930: A note on Dadoxylon (Araucarioxylon) from the Bay of Isles. In Report on the geological collections made during the voyage of the "Quest" on the ShackletonRowett Expedition to the South Atlantic and Weddell Sea in 1921-1922. Trustees of the British Museum, London: pp. 24-27.

Greenslade, P. 2006: The Invertebrates of Macquarie Island. Australian Antarctic Division, Kingston, Tasmania: xvi $+326 \mathrm{pp}$.

Greenslade, P., Farrow, R.A. \& Smith, J.M.B. 1999: Long distance migration of insects to a subantarctic island. Journal of Biogeography 26: 1161-1167.

Gremmen, N. \& Smith, V. 2004: The flora of Marion and Prince Edward Islands. Data Analyse Ecologie, Diever, Netherlands (DVD).

Gressitt, J.L. 1964: Insects of Campbell Island. Pacific Insects Monograph 7: 1-663.

Gressitt, J.L. 1970: Subantarctic entomology and biogeography. Pacific Insects Monograph 23: 295-374

Greve, M., Gremmen, N.J.M., Gaston, K.J. \& Chown, S.L. 2005: Nestedness of Southern Ocean island biotas: ecological perspectives on a biogeographical conundrum. Journal of Biogeography 32: 155-168.

Hawes, T.C., Worland, M.R., Bale, J.S. \& Convey, P. 2007a: Rafting in Antarctic springtails. Journal of Zoology doi:10.1111/j.1469-7998.2007.00355.x

Hawes, T.C., Worland, M.R., Convey, P. \& Bale, J.S. 2007b: Aerial dispersal of springtails on the Antarctic Peninsula: implications for local distribution and demography. Antarctic Science 19: 3-10.

Headland, R.K. 1989: Chronological List of Antarctic Expeditions and Related Historical Events. Cambridge University Press, 
Cambridge: $x+730$ pp.

Holdgate, M.W. 1960: The fauna of the mid-Atlantic islands. Proceedings of the Royal Society, London B 152: 550 567.

Hughes, K., Ott, S., Bölter, M. \& Convey, P. 2006: 3. Colonisation processes. In Bergstrom, D.M., Convey, P. \& Huiskes, A.H.L. (eds): Trends in Antarctic Terrestrial and Limnetic Ecosystems: Antarctica as a Global Indicator, Springer, Dordrecht: pp. 35-54.

IAATO 2006: Tourism statistics. www.iaato.org (accessed March 2007).

Jacka, T.H. \& Budd, W.F. 1998: Detection of temperature and sea-ice-extent changes in the Antarctic and Southern Ocean, 1949-96. Annals of Glaciology 27: 553-559.

Jeannel, R. 1964: Biogéographie des terres Australes de l'Océan Indien. Revue Francaise d'Entomologie 31: 319-417.

Jensen, D.B. \& Christensen, K.D. (eds) 2003: The biodiversiry of Greenland - a country study. Technical Report 55, Grønlands Naturinstitut, Nuuk: 165 pp.

Kiernan, K. \& McConnell, A. 2002: Glacier retreat and meltlake expansion at Stephenson Glacier, Heard Island World Heritage Area. Polar Record 38 (207): 297-308.

King, J.C., Turner, J., Marshall, G.J., Connally, W.M. \& LachlanCope, T.A. 2003: Antarctic Peninsula climate variability and its causes as revealed by analysis of instrumental records. Antarctic Research Series 79: 17-30.

King, P.E., Pugh, P.J.A., Fordy, M.R., Love, N. \& Wheeler, S.A.1990: A comparison of some environmental adaptations of the littoral collembolans Anuridella marina (Willem) and Anurida maritima (Guerin). Joumal of Natural History 24: 673-688.

Knox, G.A. 1994: The Biology of the Southern Ocean. Cambridge University Press, Cambridge: xiv + $444 \mathrm{pp}$.

Krivolutsky, D.A., Lebedeva, N.V. \& Gavrilo, M.V. 2004: Soil microarthropods in the feathers of Antarctic birds. Doklady Biological Sciences 397: 342-345.

Kuschel, G. \& Chown, S.L. 1995: Phylogeny and systematics of the Ectemnorhinus-group of genera (1nsecta: Coleoptera). Invertebrate Taxonomy 9: 841-863.

Laybourn-Parry, J. \& Marchant, H.J. 1992: Daphniopsis studeri (Crustacea: Cladocera) in lakes from the Vestfold Hills, Antarctica. Polar Biology 11: 631-635.

LeMasurier, W.E. \& Thomson, J.W. 1990: Volcanoes of the Antarctic Plate and Southern Oceans. Antarctic Research Series 48: 1-487.

Longton, R.E. 1988: Biology of polar bryophytes and lichens. Cambridge University Press, Cambridge: viii +391 pp.

Marshall, D.J. \& Convey, P. 2004: Latitudinal variation in habitat specificity of ameronorhroid mites. Experimental and Applied Acarology 34: 21-35.

Marshall, W.A. 1996: Biological particles over Antarctica. Nature 383: 680 .

McDowall, R.M. 2005: Falkland Islands biogeography: converging trajectories in the South Atlantic Ocean. Journal of Biogeography 32: 49-62.

McInnes, S.J. \& Pugh, P.J.A. 1998: Biogeography of limnoterrestrial Tardigrada, with particular reference to the Antarctic fauna. Journal of Biogeography 25: 31-36.

Meurk, C.D., Foggo, M.N. \& Wilson, J.B. 1994a: The vegetation of subantarctic Campbell Island. New Zealand Journal of Ecology 18: 123-168.

Meurk, C.D., Foggo, M.N., Thompson, B.M., Bathurst, E.T.J. \& Crompton, M.B. 1994b: Ion-rich precipitation and vegetation patterns on subantarctic Camphell Island. Arctic and Alpine Research 26: 281-289.

Mitchell A.D., Meurk, C.D. \& Wagstaff, S.J. 1999. Evolution of Stilbocarpa, a megaherb from New Zealand's sub-antarctic islands. New Zealand Journal of Botany 37: 205-211.

Morrone, J.J. 1998: On Udvardy's Insulantarctica province: a test from the weevils (Coleoptera : Curculionoidea). Journal of Biogeography 25: 947-955.
Mortimer, E. \& Jansen van Vuuren, B. 2007: Phylogeography of Eupodes minutus (Acari: Prostigmata) on sub-Antarctic Marion Island reflects the impact of historical events. Polar Biology' 30: 471-476.

Muñoz, J., Felicísimo, A.M., Cabezas, F., Burgaz, A.R. \& Martínez, I. 2004: Wind as a long-distance dispersal vehicle in the Southern Hemisphere. Science 304: $1144-1147$.

Navareen, R., Forrest, S.C., Dagit, R.G., Blight, L.K., Trivelpiece, W.Z. \& Trivelpiece, S.G. 2001: Zodiac landings by tourist ships in the Antarctic Peninsula region, 1989-99. Polar Record 37: 121-132.

Ochyra, R., Bednarek-Ochyra, H. \& Smith, R.I.L. In press: The moss flora of Antarctica. Cambridge University Press, Cambridge.

Ovstedal, D.O. \& Smith, R.I.L. 2001: Lichens of Antarctica and South Georgia. A Guide to Their Identification and Ecology. Cambridge University Press, Cambridge: xii +411 pp.

Peat, H.J., Clarke, A. \& Convey, P. 2007: Diversity and biogeography of the Antarctic flora. Journal of Biogeography 34: $132-146$

Pugh, P.J.A. 1993: A synonymic catalogue of the Acari from Antarctica, the sub-Antarctic 1slands and the Southern Ocean. Joumal of Natural History 27: 323-421.

Pugh, P.J.A. 1994: Non-indigenous Acari of Antarctica and the sub-Antarctic islands. Zoological Journal of the Linnean Society 110: 207-217.

Pugh, P.J.A. 1997: Acarine colonisation of Antarctica and the islands of the Southern Ocean: the role of zoohoria. Polar Record 33: 113-122.

Pugh, P.J.A. 2003: Have mites (Acarina: Arachnida) colonised Antarctica and the islands of the Southern Ocean via air currents? Polar Record 39: 239-244.

Pugh, P.J.A. 2004: Biogeography of spiders (Araneae: Arachnida) on the islands of the Southern Ocean. Journal of Natural History 38: 1461-1487.

Pugh, P.J.A. \& Davenport, J. 1997: Colonisation vs. disturbance: the effects of sustained ice-scouring on intertidal communities. Journal of Experimental Marine Biology and Ecology 210: 1-21.

Pugh, P.J.A. \& Scott, B. 2002: Biodiversity and biogeography of non-marine Mollusca on the islands of the southern Ocean. Journal of Natural History 36: 927-952.

Pugh, P.J.A., Dartnall, H.J.G. \& McInnes, S.J. 2002: The nonmarine Crustacea of Antarctica and the islands of the Southern Ocean: biodiversiry and biogeography. Joumal of Natural History 36: 1047-1103.

Quilty, P.G. \& Wheller, G. 2000: Heard Island and the McDonald Islands: a window into the Kerguelen Plateau. Papers and Proceedings of the Royal Society of Tasmania. 133: 1-12.

Ronning, O.I. 1996: The flora of Svalbard. Norsk Polarinstitut, Oslo: $184 \mathrm{pp}$.

le Roux, P.C., McGeoch, M.A., Nyakatya, M.J. \& Chown, S.L. 2005: Effects of a short-term climate change experiment on a keystone plant species in the sub-Antarctic. Global Change Biology 11: 1628-1639.

Schlichting, H.E., Speziale, B.J. \& Zink, R.M. 1978: Dispersal of algae and Protozoa by Antarctic flying birds. Antarctic Journal of the United States 13: 147-149.

Selmi, S. \& Boulinier, T. 2001: Ecological biogeography of Southern Ocean Islands: the importance of considering spatial issues. American Naturalist 158: 426-437.

Seppelt, R.D. 2004: The Moss Flora of Macquarie Island. Australian Antarctic Division, Kingston: 328 pp.

Shaw, J.D. 2005: Reproductive Ecology of Vascular Plants on Subantarctic Macquarie Island. Unpublished PhD thesis, University of Tasmania, Hobart.

Shaw, J.D, Bergstrom, D.M \& Hovenden, M. 2005: The impact of feral rats (Rattus rattus) on populations of subantarctic megaherh (Pleurophyllum hookeri). Austral Ecology 30: $118-125$. 
Shirihai, H. 2002: A Complete Guide to Antarctic Wildlife: The Birds and Marine Mammals of the Antarctic Continent and the Southern Ocean. Alula Press, Degerby: $510 \mathrm{pp}$.

Skottsberg, C. 1960: Remarks on the plant geography of the southern cold temperate zone. Proceedings of the Royal Society of London B 152: 447-457.

Slabber, S. \& Chown, S.L. 2002: The first record of a terrestrial crustacean, Porcellio scaber (Isopoda, Porcellionidae), from sub-Antarctic Marion Island. Polar Biology 25: $855-858$.

Smith, R.I.L. 1984: Terrestrial plant biology of the sub-Antarctic and Antarctic. In Laws, R.M. (ed.), Antarctic Ecology, Vol. 1, Academic Press, London: pp. 61-162.

Smith, R.I.L. 2001: Plant colonization response to climate change in the Antarctic. Folia Facultatis Scientiarium Naturalium Universitatis Masarykianae Brunensis, Geographia 25: 19-33.

Smith, V.R. 2002: Climate change in the sub-Antarctic: an illustration from Marion Island. Climate Change 52: 345-357.

Smith, V.R. \& Steenkamp, M. 1990: Climatic change and its ecological implications at a sub-Antarctic island. Oecologia 85: 14-24.

Stevens, M.I., Greenslade, P., Hogg, I.D. \& Sunnucks, P. 2006 : Examining Southern Hemisphere springrails: could any have survived glaciation of Antarctica? Molecular Biology and Evolution 23: 874-882.

Strong, J. 1967: Ecology of terrestrial arthropods at Palmer station, Antarctic Peninsula. Antarctic Research Series 10: 357-371.

Truswell, E.M., Quilty, P.G., McMinn, A., MacPhail, M.K. \& Wheller, G.E. 2005: Late Miocene vegetation and palaeoenvironments of the Drygalski Formation, Heard Island, Indian Ocean: evidence from palynology. Antarctic Science 17: 427-442.

Tweedie, C.E. \& Bergstrom, D.M. 2000: A climate change scenario for surface air temperature at subantarctic Macquarie Island. In Davison, W., Howard-Williams, C.
\& Broady. P.A. (eds): Antarctic Ecosystems: Models for Wider Ecological Understanding. New Zealand Natural Sciences, Christchurch: pp. 272-281.

Turner, J., Lachlan-Cope, T.A., Colwell, S.R. \& Marshall, G.J. 2005: A positive trend in western Antarctic Peninsula precipitation over the last 50 years reflecting regional and Antarctic-wide atmospheric circulation changes. Annals of Glaciology 41: 85-91.

Udvardy, M.D.F. 1987: The biogeographical realm Antarctica: a proposal. Journal of the Royal Society of New Zealand 17: 187-194.

Vaughan, D.G., Marshall, G.J., Connolley, W.M., Parkinson, C.L., Mulvaney, R., Hodgson, D.A., King, J.C., Pudsey, C.J. \& Turner, J. 2003: Recent rapid regional climate warming on the Antarctic Peninsula. Climate Change 60: $243-274$.

van de Vijver, B. \& Beyens, L. 1999: Biogeography and ecology of freshwater diatoms in Subantarctica: a review. Journal of Biogeography 26: 993-1000.

Wallace, P.J., Frey, F.A., Weis, D. \& Coffin, M.F. 2002: Origin and evolution of the Kerguelen Plateau, Broken Ridge, and Kerguelen Archipelago: Editorial, Joumal of Petrology 43: 1105-1108.

Walther, G.-R., Post, E., Convey, P., Parmesan, C., Menzel, M., Beebee, T.J.C., Fromentin, J.-M., Hoegh-Guldberg, O. \& Bairlein, F. 2002: Ecological responses to recent climate change. Nature 416: 389-395.

Wardle, P. 1991: Vegetation of New Zealand. Cambridge University Press, Cambridge: 672 pp.

Woehler, E.J., Cooper, J., Croxall, J.P., Fraser, W.R., Kooyman, G.L., Miller, G.D., Nel, D.C., Patterson, D.L., Peter, H-U, Ribic, C.A., Salwicka, K., Trivelpiece, W.Z. \& Weimerskirch, H. 2001: A statistical assessment of the status and trends of Antarctic and subantarctic seabirds. Report on SCAR BBS Workshop on Southern Ocean Seabird Populations: 1-43.

(accepted 30 July 2007) 